\title{
Work-related respiratory disorders among street sweepers in Cairo, Egypt, a comparative study
}

\author{
Nayera S. Mostafa, Mona A. Abdel-Hamid, Lamyaa S. AlBagoury \\ Community, Environmental and Occupational Medicine Department, Faculty of \\ Medicine, Ain Shams University, Cairo, Egypt
}

\begin{abstract}
Respiratory diseases are one of the main morbidities to which street sweepers are exposed due to inhalation of road dust. The problem is rising in developing countries due to lack of occupational safety and health measures. Cumulative and long exposure to dust negatively affects lung function parameters. Objectives: This study aims to measure and compare the lung functions and respiratory morbidity among a group of street sweepers and a comparison group of office workers in Abbasia district, Cairo, Egypt. Methods: This study was a cross sectional study which included 107 street sweepers and 104 office workers. The study participants were asked about their sociodemographic, occupational and medical data. Their lung functions were measured. Results: The percentage of participants with reduced FEV1, reduced FVC and reduced FEV1/FVC were significantly higher in the sweepers than in the control group $(62.1 \%$ versus $34.6 \%, 58.3 \%$ versus $44.2 \%$, and $32 \%$ versus $18.3 \%$ respectively). Chronic cough was also significantly higher in the sweepers than in the control group (17.5\% versus $5.8 \%$ ). Reduced $\mathrm{FVC} \%$ was significantly associated to older age and longer duration of employment. Reduced FEV1/FVC was positively associated to smoking among sweepers. Conclusions: Hazardous exposure to dust during street sweeping can cause respiratory symptoms such as cough and a significant reduction in pulmonary function.

Keywords: dust exposure, pulmonary functions, respiratory disorder, street sweeper.
\end{abstract}

\section{Introduction}

Street sweepers carry on an essential role in the continuous process of city cleaning. Since this job deals with wastes and dirt, street sweepers are exposed to several hazards ${ }^{(1,2)}$. Occupational Respiratory diseases are one of the main morbidities to which they are exposed ${ }^{(3,4)}$ due to inhalation of road dust which consists of a mixture of bio-aerosols ${ }^{(5)}$, high concentrations of dust, continuous production of viable microorganisms (bacteria, and fungi), endotoxins ${ }^{(6)}$, motor vehicle exhaust, wearing dust of car brakes and tires ${ }^{(7)}$, diesel soot particles and lead. In addition to the products of atmospheric transformation, such as ozone and sulfate particles ${ }^{(8)}$. Long term inhalation of such complex dust during street sweeping causes impairment of lung function and may cause respiratory illnesses ${ }^{(7)}$.

Bioaerosols are formed during handling of wastes through the action of microorganisms on them. This may lead to infectious, allergenic, or toxic hazards ${ }^{(5,9)}$.

Street sweeping and waste collection may lead to a group of respiratory disorders, for example, mucous membrane irritation, rhinitis, allergy, asthma, bronchitis, conjunctivitis, hypersensitivity pneumonitis, allergic broncho-pulmonary dermatitis, and diarrhea ${ }^{(5,10,11)}$. 
The problem is rising in developing countries due to several reasons, of which is rapid urbanization (12). In addition, occupational safety and health measures taken to prevent sweepers' morbidities are not applied in most developing countries, which in turn predispose them to the development of respiratory illnesses, for example, chronic obstructive pulmonary diseases (13). The seriousness and complexity of this problem arise from the fact of limited resources, technologies, low socioeconomic standard and low educational level $^{(14)}$.

Other morbidities include hazards of infection, cut wounds, traffic accidents and exposure to a high level of noise especially in crowded areas (15). Cardiovascular and eye diseases are also common among sweepers ${ }^{(3)}$.

Cumulative exposure to dust and long duration of exposure in street sweeping and other jobs lead to a decrease in FEV1 and other lung function parameters ${ }^{(16,17)}$.

According to CDC, Chronic Obstructive Pulmonary Disease (COPD) causes $3.09 \%$ of total DALYs worldwide. In Egypt, it is the fourth cause of death among the Egyptian population ${ }^{(18)}$.

Bureau of Labor Statistics in US mentioned that respiratory conditions were one of the three most prevalent health impairments among American workers in $2011^{(19)}$.

The objective of this study was to measure and compare the lung functions and respiratory morbidity among a group of street sweepers and a comparison group of office workers in Abbasia district, Cairo, Egypt. It also aims to identify possible risk factors of such morbidity.

\section{Subjects and Methods}

This study was a cross-sectional one. It was carried out during the period from February to July 2014. The study included two groups who were both males. The study group comprised 107 street sweepers working in Abbasia district, Cairo, Egypt. The comparison group comprised 104 office workers in Ain Shams University in the same district. They were matched with study group regarding age and gender. The sample was calculated using Epi info 2002 using prevalence $18 \%{ }^{(20)} \pm 8 \%$ SD of street sweepers complaining of respiratory manifestations (CI 95\%). The sample was calculated as 89 participants in each group and it was increased according to the availability of participants.

Group meetings of the subjects were carried out to explain the purpose of the study and to ensure their cooperation. At the same time, demonstration of the maneuver of measuring lung functions was done several times to ensure that they can competently perform it. A pretested questionnaire was used to record the required information such as sociodemographic factors (age, smoking, education, etc...), occupational history (duration of exposure, use of personal protective equipment, etc...), medical history and respiratory complaints within the previous 3 months and findings of pulmonary function testing performed for the workers.

The subjects' weight and height were measured and body mass index (BMI) was calculated. The lung functions; Forced vital capacity (FVC), Forced expiratory volume 1 (FEV1), FEV1/FVC and Peak expiratory flow rate (PEF) were measured using digital spirometer (A23-053.06732 Spirolab III, MIR, Italy). The best trial measurement was recorded after 3 successive trials. Subjects who did not perform an acceptable maneuver after three attempts were excluded from the 
study. Predicted values were calculated according to subject's gender, age and height. Spirometry values (FVC, FEV1, FEV1/FVC and PEF) less than $80 \%$ of predicted values were considered reduced.

Data collection and lung functions measurements of the sweepers were carried out in administrative offices next to their working sites. Regarding the comparison group, data was collected in their working offices.

Approval of the Public Authority for Cleanliness and Beautification in Cairo and administrative approval of Ain Shams University were obtained. The study participants were assured of the confidentiality of the data and their verbal consent was obtained.

The data collected were analyzed using SPSS program version 20. Descriptive (frequency distribution tables, mean and standard deviation) as well as inferential analysis (chi-squared test) were performed. Based on the results of the univariate analysis, logistic regression analysis was performed to select all the independent variables that are believed to have significant effect on the dependent variables. Backward method was used. The estimated models provide the direct effect of each independent variable on the dependent variables. The significance level was set at $\mathrm{P}<0.05$.

\section{Results}

The socio-demographic and personal characteristics of the street sweepers as well as the control group are described in table 1. Participants above or equal to 40 years old were about $61.2 \%$ and $54.6 \%$ in the sweepers and the control groups respectively. The majority of the participants in the sweepers and the control groups were married $(95.1 \%$ and $78.8 \%$ respectively). Regarding the education of the participants; about $80.6 \%$ of those in the sweepers group were not educated while about $93.3 \%$ of those in the control group were educated. Smokers represent $35 \%$ and $45.2 \%$ of the sweepers and the control groups respectively. Regarding the BMI; the majority of the participants in the sweepers group were normal and overweight $(38.8 \%$ and $40.8 \%$ respectively), on the other hand, the majority of the participants in the control group were overweight and obese $(32.7 \%$ and $44.2 \%$ respectively). There were statistically significant difference between both groups regarding marital status, education and BMI ( $\mathrm{p}$ value $<0.01$ ).

By comparing the respiratory symptoms of the study groups, it was found that the percentage of participants with chronic cough were significantly higher in the sweepers than in the control group $(17.5 \%$ versus $5.8 \%$ ), however, the percentage of participants with wheezes were significantly lower in the sweepers than in the control group (1\% versus $23.1 \%$ ). There was no statistically significant difference in the percentage of chest tightness between both groups (table 2).

By comparing the pulmonary function measurements of the study groups, it was found that the percentage of participants with reduced FEV1, reduced FVC and reduced FEV1/FVC were significantly higher in the sweepers than in the control group $(62.1 \%$ versus $34.6 \%, 58.3 \%$ versus $44.2 \%$, and $32 \%$ versus $18.3 \%$ respectively). On the other hand, there was no statistically significant difference in the percentage participants with reduced PEF between both groups (table 2).

Table 3 describes the occupational history of the street sweepers group; about $65 \%$ of the participants have been working as street sweepers for less than 10 years with mean duration of employment of $9.30 \pm 7.66$ years. 
About $69 \%$ of them were permanent workers. Most of them (91.2\%) were full timers ( $\geq 5$ days/week). About $89.3 \%$ of them were working less than 8 hours per day with a mean of $8.32 \pm 1.139$ hours per day. No one of the participating street sweepers wear face masks. Only $42.7 \%$ of them frequently washed their hands and face after work while $56.3 \%$ of them seldom did. The method of garbage collection used by the majority of them was the wheel barrow (88.3\%). More than $95 \%$ of them did not get previous training on health and safety. Regarding medical insurance, $80.6 \%$ had partial insurance, $10.7 \%$ had full insurance, while the rest $(8.7 \%)$ did not have any kind of insurance.

Studying the association between pulmonary function measurements and socio-demographic and occupational factors among street sweepers revealed that sweepers with normal and those with reduced $\mathrm{FVC} \%$ differs significantly in their age as well as their duration of employment where the percentage of sweepers with reduced $\mathrm{FVC} \%$ was higher among sweepers more than or equal to 40 years old compared to those with normal $\mathrm{FVC} \%$ in the same age group ( $70 \%$ versus $48.8 \%$ ). In addition, the percentage of sweepers working for 10 years or more who had reduced FVC\% is higher than those who were normal (45.8\% versus $20.9 \%$ ).

Regarding $\mathrm{FEV}_{1} / \mathrm{FVC}$, sweepers with normal and those with reduced FEV1/FVC differs significantly in their current smoking status where the percentage of smokers who had reduced $\mathrm{FEV}_{1} / \mathrm{FVC}$ was higher than those who were normal $(78 . \%$ versus $58.6 \%$ )

Regarding $\mathrm{FEV}_{1} \%$, there were no statistically significant differences in age, current smoking and duration of employment between street sweepers with normal and those with reduced $\mathrm{FEV}_{1} \%$ (Table 4).

Table 5 shows the independent factors of reduced pulmonary function measurements among street sweepers, according to logistic regression model. Current smoking appears to be independently associated with the likelihood of impaired $\mathrm{FEV}_{1} \%$ and impaired $\mathrm{FEV}_{1} / \mathrm{FVC}$ (Odds Ratio= 2.32 and 2.54respectively). On the other hand, longer duration of employment $\quad(\geq \quad 10 \quad$ years $)$ independently associated with the likelihood of impaired FVC (Odds Ratio= 2.19).

\section{Discussion}

In the current study, most of the municipal street sweepers interviewed and examined were married males, and of low socioeconomic level indicated by their high illiteracy rate. Street sweeping and collecting waste is a job that is usually performed by poor people, mostly males, being responsible for families of large size, and with low educational and socioeconomic levels. This applies to Egypt (21) and other developing countries ${ }^{(22)}$.

Results of this study showed that cough as a symptom related to chronic bronchitis was significantly more common among street sweepers $(17.5 \%)$ than among office workers representing the control group (5.8\%). Several studies have shown the high prevalence of cough among street sweepers. A study done in Beni Suef in Egypt revealed that cough was significantly more frequent among those working in street sweeping and waste collection than clerks $(18.1 \%$ vs. $7.1 \%$ respectively) ${ }^{(20)}$.Another study in Nigeria showed a higher prevalence of respiratory disorders among street sweepers than among the control group, mainly cough, catarrh, and 
sneezing ${ }^{(7)}$. Two studies in India found a significant higher prevalence of chronic respiratory diseases among sweepers than among the comparison group $^{(3,23)}$. It is likely that exposure to soil dust, traffic exhaust particles and fumes, together with other biological materials may all contribute to irritation of the respiratory tract causing cough and other respiratory symptoms.

Respiratory function indices of street sweepers measured in this study were significantly lower than those for office workers. Results also showed that factors independently causing this lowering were current smoking for both FEV1 and FEV1/FVC, and ten years or more duration of employment for FVC. All of the street sweepers enrolled in this study mentioned the nonuse of the personal protective equipment as face masks. This was similar to another study performed in Egypt ${ }^{(22)}$. Together with their exposure to different types of dust, this might explain the reasons for the presence of respiratory complains and the reduction in the respiratory functions among this group. Most of the researchers studying the effect of exposure to risk factors associated with waste collection and street sweeping, on respiratory functions, have found the same results $(23,24)$

A study on Nigerian female sweepers revealed reduction in the measured lung function parameters, but this reduction was not statistically significant ${ }^{(25)}$.Similarly, a study on street sweepers in Bangkok reported that the mean FVC, FEV1 and FEF25$75 \%$ of the street sweepers were significantly less than the mean predicted values ${ }^{(26)}$.

When studying the influence of smoking on the respiratory effects of occupational dust exposure, a population-based study found that chronic bronchitis was common among workers exposed to mineral dust and that smoking doubles its risk, and this was associated with lowered FEV1/FVC ratio (27). In Spain, a cross sectional study in an industrial area, showed a $52 \%$ prevalence of occupational exposure to dust, gases and fumes. There was an association of these exposures with airway obstruction and chronic bronchitis independently of smoking. The lowering of lung function indices was more common among individuals exposed for at least 15 years ${ }^{(28)}$.

Studies done in developing countries had similar results as the current study. In Pakistan, a cross sectional study found that pulmonary function tests had lower values for the sweepers group than the control one and the pattern of pulmonary airway obstruction was proportional to the duration of occupational exposure to dust. The study also recommended the use of spirometry as a simple, noninvasive tool to detect preclinical respiratory disease among exposed workers ${ }^{(13)}$. One of two studies done in India showed a significant decrease in pulmonary function indices among street cleaners than their matched controls, namely FVC, FEV1, PEFR, FEF25-75\% and FEF 200-1200. Those indices were also reduced after sweeping. In their study, FEV1/FVC was increased which was against obstructive pulmonary disorder and suggestive of restrictive ones. The same study also revealed that pulmonary function values after sweeping also showed a significant reduction ${ }^{(29)}$. The other Indian study found a significant decrease in PEFR, FEV1, FEV1/FVC ratio $<80 \%$ and FEF 25\%-75\% measured for street sweepers indicating obstructive pulmonary disease ${ }^{(30)}$. The values of lung function indices were all reduced for street sweepers in Nigeria than their controls although the difference was 
not statistically significant. This was attributed to the short duration of occupational exposure as sweepers ${ }^{(8)}$.

\section{Conclusions}

and

\section{recommendations}

From this study, it is concluded that hazardous exposure to dust caused by street sweeping can cause respiratory complaints such as cough and a significant reduction in pulmonary function indices measured by spirometry suggestive of obstructive lung disease.

It is recommended that occupational health services should provide and train street sweepers to use protective equipments as face masks to decrease the risk of exposure to road dust. They should also encourage quitting smoking. Periodic clinical examination should be done for early detection of respiratory impairments.

\section{References}

1) Krajewski JA, Tarkowski S, Cyprowski M, SzarapinskaKwaszewska $J$ and Dudkiewicz B, 2002. Occupational exposure to organic dust associated with municipal waste collection and management. Int $\mathbf{J}$ Occup Med Environ Health; 15: 289301.

2) Dutkiewicz J, 1997. Bacteria and fungi in organic dust as potential health hazard. Ann Agric Environ Med; 4: 11-6.

3) Yogesh DS and Sanjay PZ, 2008. A Study of Morbidity Pattern in Street Sweepers: A Cross-sectional Study. Indian J Community Med.; 33(4): 2248.

4) Diggikar UA, 2004. Health status of street sweepers with reference to lung function tests (Dissertation) Pune University.
5) Lavoie J and Dunkerley C, 2002. Assessing waste collectors' exposure to bioaerosols. Aerobiologia ;18: $277-$ 85.

6) Krajewski JAI, SzarapinskaKwaszewska J, Dudkiewicz B, Cyprowski M, Tarkowski S, Konczalik J and Stroszejn-Mrowca G, 2001. Assessment of exposure to bioaerosols in workplace ambient air during municipal waste collection and disposal. Med Pr ; 52(6): 417-22.

7) Nku CO, Peters EJ, Estiet Al, Oku $O$ and Osim EE, 2005. Lung function, Oxygen Saturation and Symptoms among Street Sweepers in CalabarNigeria.Niger J physiol Sci ; 20 (1-2): 79-84.

8. WHO, 2014. Air pollution. (Cited 2014 Dec 8); Available at: http://www.who.int/ceh/risks/cehair/en

9) Nielsen E, Breum $N$, Nielsen $B$, W"urtz H, Poulsen $\mathrm{O}$ and Midtgaard U, 1997. Bioaerosol exposure in waste collection: a comparative study on the significance of collection equipment, type of waste and seasonal variation. Ann Occup Hyg ; 41: 325-44.

10) Wouters I, Hilhorst $S$, Kleppe $P$, et al, 2002. Upper airway inflammation and respiratory symptoms in domestic waste collectors. Occup Environ Med; 59:106-12.

11) Allmers $H$, Huber $H$ and Baur $\mathbf{X}, 2000$. Two year follow-up of a garbage collector with allergic bronchopulmonary aspergillosis (ABPA). Am J Ind Med; 37: 438-42.

12) Ramachandra $T$ and Varghese S, 2003. Exploring possibilities of achieving sustainability in solid waste management. Indian J Environ Health; 45: 255-64.

13) Anwar SK, Mehmood N, Nasim $N$, Khurshid $M$ and Khurshid B, 2013. Sweeper's lung disease: a crosssectional study of an overlooked illness among sweepers of Pakistan. 
International Journal of COPD; 8:1937.

14) Stambuli P, 2012. Occupational respiratory health symptoms and associated factors among street sweepers in ilala municipality. Master thesis of Public Health Dissertation, Muhimbili University of Health and Allied Sciences.

15) LeGrande D, 2014. Occupational Health and Safety Hazards in Public and Governmental Services.Chapter 101 - Public and Government Services. Encyclopedia of Occupational Health and Safety. Fourth edition. (Cited 2014 Nov 20); Available at: http://www.ilocis.org/documents/chpt1 01e.htm

16) Ulvestad B, Bakke B, Eduard W, Kongerud $J$ and Lund MB, 2001. Cumulative exposure to dust causes accelerated decline in lung function in tunnel workers. Occup Environ Med; 58: 663-9.

17) Post W, Heederik D and Houba $\mathbf{R}$, 2000. Decline in lung function related to exposure and selection processes among workers in the grain processing and animal feed industry. Occup Environ Med; 55: 349-55.

18) GBD Compare, 2010. (Cited 2014 June 26); Available from: http://vizhub.healthdata.org/gbd-

\section{compare/}

19) Bureau of Labor Statistics, United States Department of Labor. 2012. Incidence rates and numbers of nonfatal occupational illnesses by major industry sector, category of illness, and ownership, 2011. (Cited 2015 Jan 24); Available from: www.bls.gov/news.release/osh.t06.htm 20) Ewis AA, Rahma MA, Mohamed ES, Hifnawy TM and Arafa AE, 2013. Occupational Health-Related Morbidities Among Street Sweepers And Waste Collectors At Beni-Suef, Egypt. Egyptian Journal of Occupational Medicine; 37 (1): 79-94
21) Abdel-Wahab EW, Eassa SM, Lotfi SE, El-Masry SA, Shatat HZ, and Kotkat AM, 2014. Adverse Health Problems among Municipality Workers in Alexandria (Egypt). Int J Prev Med; 5(5): 545-56.

22) Nagaraj C, Shivaram C, Jayanth KK and Narasimha NS, 2004. A study of morbidity and mortality profile of sweepers working under Bangalore City Corporation. IJOEM; 8(2): 11-8.

23) Yogesh SD and Sanjay PZ, 2008. Respiratorymorbidity among street sweepers working at Hanumannagar Zone of Nagpur Municipal Corporation, Maharashtra. Indian J Public Health; 52(3): 147-49.

24) Johncy, SS, Dhanyakumar G, Kanyakumari and Samuel TV, 2014. Chronic Exposure to Dust and Lung Function Impairment: A Study on Female Sweepers in India. National Journal of Physiology, Pharmacy \& Pharmacology; 4 (1):15

25) Nku CO, Peters EJ, Eshiet AI, Oku $O$ and Osim EE, 2005. Lung function, oxygen saturation and symptoms among street sweepers in Calabar-Nigeria. Nigerian Journal of Physiological Sciences;20(1-2):79-84.

26) Wasuthep B, 2005. A comparative study of lung function of street sweepers in inner and outer regions of Bangkok metropolis.

Dissertation.Thailand: Mahidol University.

27) De Meer G, Kerkhof $M$, Kromhout H, Schouten JP and Heederik D, 2004. Interaction of atopy and smoking on respiratory effects of occupational dust exposure: a general population-based study. Environmental Health: A Global Access Science Source; 3: 6. (doi:10.1186/1476-069X3-6)

28) Jaén Á, Zock JP, Kogevina M, Ferrer A and Marín A, 2006. Occupation, smoking, and chronic obstructive respiratory disorders: a 
cross sectional study in an industrial area of Catalonia, Spain. Environmental Health: A Global Access Science Source; 5: 2. (doi:10.1186/1476-069X-52)

29) Johncy SS., Dhanyakumar G., Samuel TV., Ajay KT. and Bondade SY, 2013. Acute Lung Function Response to Dust in Street Sweepers.
Journal of Clinical and Diagnostic Research; 7(10): 2126-9. (doi: 10.7860/JCDR/2013/5818.3449)

30) Shadab M, Agrawal DK, Ahmad $Z$ and Aslam $M$, 2013. A cross sectional study of Pulmonary Function Tests in street cleaners in Aligarh, India. Biomedical Research; 24 (4): 449-52. 
Table 1: Socio-Demographic and Personal Characteristics of the Study Groups

\begin{tabular}{|c|c|c|c|c|c|c|c|c|}
\hline \multirow[t]{2}{*}{ Characteristic } & \multicolumn{2}{|c|}{$\begin{array}{l}\text { Sweepers } \\
(\mathrm{N}=103)\end{array}$} & \multicolumn{2}{|c|}{$\begin{array}{l}\text { Control } \\
(\mathrm{N}=104)\end{array}$} & \multicolumn{2}{|c|}{\begin{tabular}{|l|} 
Total \\
$(\mathrm{N}=\mathbf{2 0 7})$
\end{tabular}} & \multirow[t]{2}{*}{$\mathbf{X}^{2}$} & \multirow[t]{2}{*}{ p-value } \\
\hline & $\mathrm{N}$ & $\%$ & $\mathrm{~N}$ & $\%$ & $\mathrm{~N}$ & $\%$ & & \\
\hline $\begin{array}{l}\text { Age group } \\
\quad<40 \text { years } \\
\geq 40 \text { years }\end{array}$ & $\begin{array}{l}40 \\
63\end{array}$ & $\begin{array}{l}38.8 \\
61.2\end{array}$ & $\begin{array}{l}54 \\
50\end{array}$ & $\begin{array}{l}51.9 \\
48.1\end{array}$ & $\begin{array}{l}94 \\
113\end{array}$ & $\begin{array}{l}45.4 \\
54.6\end{array}$ & 3.576 & 0.059 \\
\hline $\begin{array}{l}\text { Marital status } \\
\quad \text { Single } \\
\text { Married }\end{array}$ & $\begin{array}{l}5 \\
98\end{array}$ & $\begin{array}{l}4.9 \\
95.1\end{array}$ & $\begin{array}{l}22 \\
82\end{array}$ & $\begin{array}{l}21.2 \\
78.8\end{array}$ & $\begin{array}{l}27 \\
180\end{array}$ & $\begin{array}{l}13.0 \\
87.0\end{array}$ & 12.121 & $0.0001 *$ \\
\hline $\begin{array}{l}\text { Education } \\
\text { Not educated } \\
\text { Educated }\end{array}$ & $\begin{array}{l}83 \\
20\end{array}$ & $\begin{array}{l}80.6 \\
19.4\end{array}$ & $\begin{array}{l}7 \\
97\end{array}$ & $\begin{array}{l}6.7 \\
93.3\end{array}$ & $\begin{array}{l}90 \\
117\end{array}$ & $\begin{array}{l}43.5 \\
56.5\end{array}$ & 114.851 & $0.0001 *$ \\
\hline $\begin{array}{l}\text { Smoking } \\
\text { Smoker } \\
\text { Non-smoker }\end{array}$ & $\begin{array}{l}36 \\
67\end{array}$ & $\begin{array}{l}35.0 \\
65.0\end{array}$ & $\begin{array}{l}47 \\
57\end{array}$ & $\begin{array}{l}45.2 \\
54.8\end{array}$ & $\begin{array}{l}83 \\
124\end{array}$ & $\begin{array}{l}40.1 \\
59.9\end{array}$ & 2.260 & 0.133 \\
\hline $\begin{array}{l}\text { BMI } \\
\text { Underweight } \\
\text { Normal BMI } \\
\text { Overweight } \\
\text { Obese }\end{array}$ & $\begin{array}{l}2 \\
40 \\
42 \\
19\end{array}$ & $\begin{array}{l}1.9 \\
38.8 \\
40.8 \\
18.4\end{array}$ & $\begin{array}{l}2 \\
22 \\
34 \\
46\end{array}$ & $\begin{array}{l}1.9 \\
21.2 \\
32.7 \\
44.2\end{array}$ & $\begin{array}{l}4 \\
62 \\
76 \\
65\end{array}$ & $\begin{array}{l}1.9 \\
30.0 \\
36.7 \\
31.4\end{array}$ & 17.279 & $0.001 *$ \\
\hline
\end{tabular}

* Association is significant at 0.01 level 
Table 2: Respiratory Symptoms and Pulmonary Function Measurements of the Study Groups

\begin{tabular}{|c|c|c|c|c|c|c|c|c|}
\hline \multirow{2}{*}{$\begin{array}{l}\text { Respiratory } \\
\text { symptoms and } \\
\text { measurements }\end{array}$} & \multicolumn{2}{|c|}{ Sweepers } & \multicolumn{2}{|c|}{ Control } & \multicolumn{2}{|c|}{ Total } & \multirow{2}{*}{$\mathbf{X}^{2}$} & \multirow[b]{2}{*}{ p-value } \\
\hline & $\mathrm{N}$ & $\%$ & $\mathrm{~N}$ & $\%$ & $\mathrm{~N}$ & $\%$ & & \\
\hline Chronic cough & 18 & 17.5 & 6 & 5.8 & 24 & 11.6 & 6.919 & 0.009 \\
\hline Chest tightness & 20 & 19.4 & 22 & 21.2 & 42 & 20.3 & 0.096 & 0.756 \\
\hline Wheezes & 1 & 1.0 & 24 & 23.1 & 25 & 12.1 & 23.815 & $0.0001 * *$ \\
\hline Reduced FEV1 & 64 & 62.1 & 36 & 34.6 & 100 & 48.3 & 15.695 & $0.0001 * *$ \\
\hline Reduced FVC & 60 & 58.3 & 46 & 44.2 & 105 & 51.0 & 3.818 & $0.049 *$ \\
\hline Reduced FEV1/FVC & 33 & 32.0 & 19 & 18.3 & 52 & 25.1 & 5.216 & $0.022 *$ \\
\hline Reduced PEF & 97 & 94.2 & 92 & 88.5 & 189 & 91.3 & 2.127 & 0.145 \\
\hline
\end{tabular}

*Association is significant at 0.05 level

** Association is significant at 0.01 level 
Table 3: Occupational history of the Street Sweepers Group

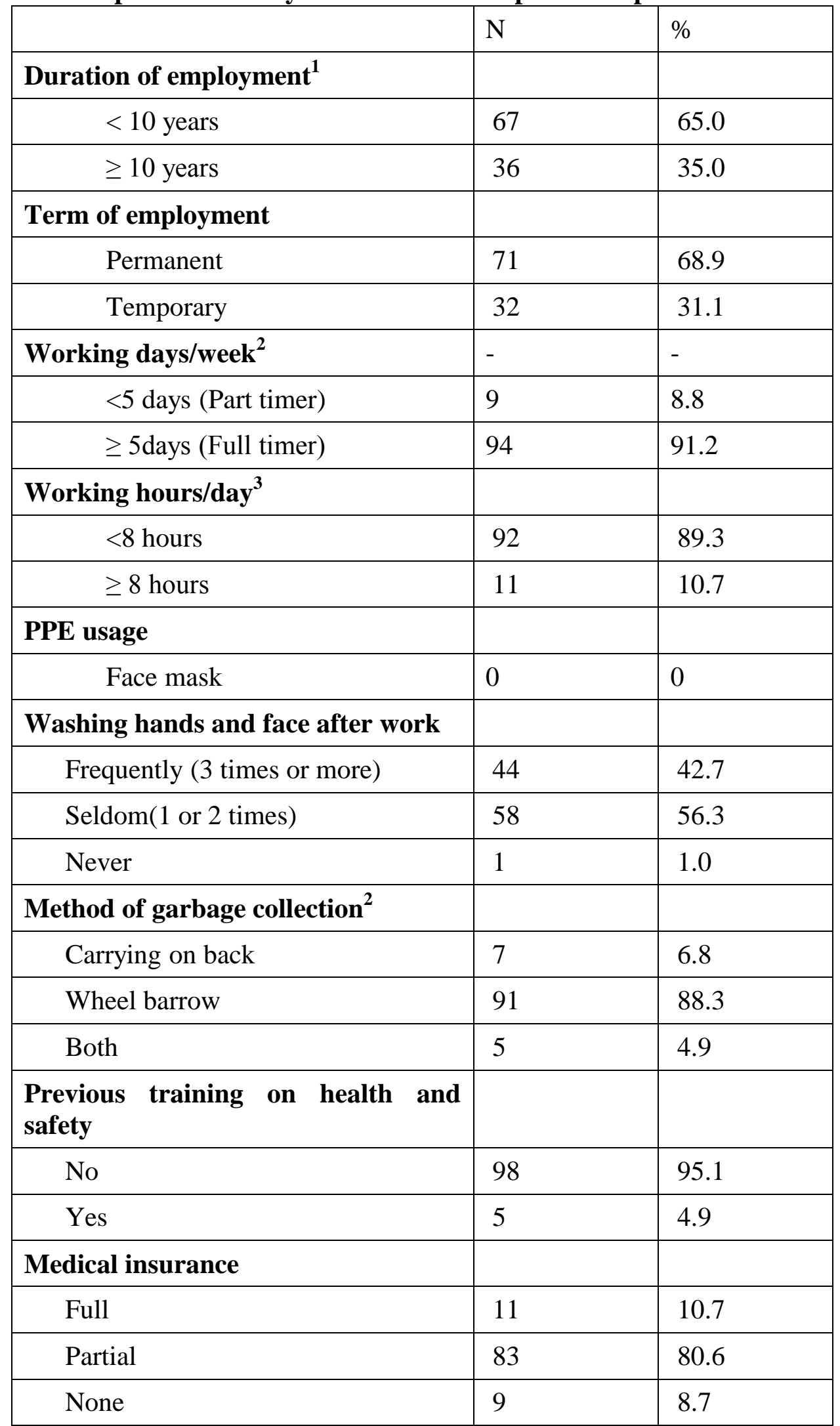

${ }^{1}$ Mean duration of employment $=9.30 \pm 7.66$

${ }^{2}$ Median working days/week $=6$

${ }^{3}$ Mean working hours/day $=8.32 \pm 1.139$ 
Table 4: Association between Pulmonary Function Measurements and Sociodemographic and Occupational Factors among Street Sweepers

\begin{tabular}{|c|c|c|c|c|c|c|c|c|c|c|c|c|}
\hline \multirow{3}{*}{ Factor } & \multicolumn{4}{|c|}{$\mathrm{FEV}_{1} \%$} & \multicolumn{4}{|c|}{ FVC\% } & \multicolumn{4}{|c|}{$\mathrm{FEV}_{1} / \mathrm{FVC}$} \\
\hline & \multicolumn{2}{|c|}{ Normal } & \multicolumn{2}{|c|}{ Reduced } & \multicolumn{2}{|c|}{ Normal } & \multicolumn{2}{|c|}{ Reduced } & \multicolumn{2}{|c|}{ Normal } & \multicolumn{2}{|c|}{ Reduced } \\
\hline & $\mathbf{N}$ & $\%$ & n & $\%$ & $\mathbf{N}$ & $\%$ & $\mathbf{n}$ & $\%$ & $\mathbf{N}$ & $\%$ & n & $\%$ \\
\hline \multicolumn{13}{|l|}{ Age group } \\
\hline$<40$ years & 18 & 46.2 & 22 & 34.4 & 22 & 51.2 & 18 & 30.0 & 26 & 37.1 & 14 & 42.4 \\
\hline$\geq 40$ years & 21 & 53.8 & 42 & 65.6 & 21 & 48.8 & 42 & 70.0 & 44 & 62.9 & 19 & 57.6 \\
\hline Test of significance & \multicolumn{4}{|c|}{$\mathrm{X}^{2}=1.415, \mathrm{p}=0.234$} & \multicolumn{4}{|c|}{$\mathrm{X}^{2}=4.723, \mathrm{p}=0.03^{*}$} & \multicolumn{4}{|c|}{$\mathrm{X}^{2}=0.263, \mathrm{p}=0.608$} \\
\hline \multicolumn{13}{|l|}{ Current smoking } \\
\hline Non-smoker & 18 & 46.2 & 18 & 28.1 & 14 & 32.6 & 22 & 36.7 & 29 & 41.4 & 7 & 21.2 \\
\hline Smoker & 21 & 53.8 & 46 & 71.9 & 29 & 67.4 & 38 & 63.3 & 41 & 58.6 & 26 & 78.8 \\
\hline Test of significance & \multicolumn{4}{|c|}{$\mathrm{X}^{2}=3.464, \mathrm{p}=0.063$} & \multicolumn{4}{|c|}{$\mathrm{X}^{2}=0.186, \mathrm{p}=0.666$} & \multicolumn{4}{|c|}{$\mathrm{X}^{2}=4.032, \mathrm{p}=0.045^{*}$} \\
\hline \multicolumn{13}{|l|}{$\begin{array}{l}\text { Duration } \\
\text { employment }\end{array}$} \\
\hline$<10$ years & 27 & 69.2 & 40 & 62.5 & 34 & 79.1 & 32 & 54.2 & 42 & 60.0 & 25 & 75.8 \\
\hline$\geq 10$ years & 12 & 30.8 & 24 & 37.5 & 9 & 20.9 & 27 & 45.8 & 28 & 40.0 & 8 & 24.2 \\
\hline Test of significance & \multicolumn{4}{|c|}{$\mathrm{X}^{2}=0.483, \mathrm{p}=0.487$} & \multicolumn{4}{|c|}{$\mathrm{X}^{2}=6.716, \mathrm{p}=0.01 * *$} & \multicolumn{4}{|c|}{$\mathrm{X}^{2}=2.449, \mathrm{p}=0.118$} \\
\hline
\end{tabular}

*Association is significant at 0.05 level.

** Association is significant at 0.01 level. 
Table 5: Logistic Regression Analysis of Independent Factors of Reduced Pulmonary Function Measurements among Street Sweepers

\begin{tabular}{|c|c|c|c|c|c|}
\hline \multirow[b]{2}{*}{ Independent Factor* } & \multirow[b]{2}{*}{$\boldsymbol{\beta}$} & \multirow[b]{2}{*}{ p-value } & \multirow[b]{2}{*}{$\mathbf{O R} * *$} & \multicolumn{2}{|c|}{$95 \% \mathrm{CI}$} \\
\hline & & & & $\begin{array}{l}\text { Lower } \\
\text { Bound }\end{array}$ & $\begin{array}{l}\text { Upper } \\
\text { Bound }\end{array}$ \\
\hline \multicolumn{6}{|l|}{$\mathrm{FEV}_{1} \%$} \\
\hline $\begin{array}{l}\text { Current smoking } \\
\text { Non-smoker }\left(\operatorname{Ref}^{\#}\right) \\
\text { Smoker }\end{array}$ & 0.841 & 0.050 & 2.32 & 1.001 & 5.373 \\
\hline Constant & -0.057 & 0.866 & & & \\
\hline \multicolumn{6}{|l|}{ FVC\% } \\
\hline $\begin{array}{l}\begin{array}{l}\text { Duration of } \\
\text { employment }\end{array} \\
\quad<10 \text { years (Ref) } \\
\quad \geq 10 \text { years }\end{array}$ & 1.159 & 0.011 & 3.19 & 1.302 & 7.806 \\
\hline Constant & -0.061 & 0.806 & & & \\
\hline \multicolumn{6}{|l|}{$\mathrm{FEV}_{\mathbf{1}} / \mathrm{FVC}$} \\
\hline $\begin{array}{l}\text { Current smoking } \\
\text { Non-smoker (Ref) } \\
\text { Smoker }\end{array}$ & 0.931 & 0.058 & 2.54 & 0.968 & 6.645 \\
\hline Constant & -1.386 & 0.001 & & & \\
\hline
\end{tabular}

* Variables entered on step 1: Age group, smoking and duration of employment ${ }^{\#}$ Ref: Reference category 